\title{
Hyperpolarization-Activated Cyclic Nucleotide-Gated Channels in Olfactory Sensory Neurons Regulate Axon Extension and Glomerular Formation
}

\author{
Arie S. Mobley, ${ }^{1 \star}$ Alexandra M. Miller, ${ }^{2 \star}$ Ricardo C. Araneda, ${ }^{3}$ Lydia R. Maurer, ${ }^{1}$ Frank Müller, ${ }^{4}$ and Charles A. Greer ${ }^{1,2}$ \\ ${ }^{1}$ Department of Neurosurgery and Neurobiology, ${ }^{2}$ Interdepartmental Neuroscience Program, Yale University School of Medicine, New Haven, Connecticut \\ 06520-8082, 32Department of Biology, University of Maryland, College Park, Maryland 20742-4415, and 4Institute of Structural Biology and Biophysics-1, \\ Forschungszentrum Jülich, D-52425 Jülich, Germany
}

\begin{abstract}
Mechanisms influencing the development of olfactory bulb glomeruli are poorly understood. While odor receptors (ORs) play an important role in olfactory sensory neuron (OSN) axon targeting/coalescence (Mombaerts et al., 1996; Wang et al., 1998; Feinstein and Mombaerts, 2004), recent work showed that G protein activation alone is sufficient to induce OSN axon coalescence (Imai et al., 2006; Chesler et al., 2007), suggesting an activity-dependent mechanism in glomerular development. Consistent with these data, OSN axon projections and convergence are perturbed in mice deficient for adenylyl cyclase III, which is downstream from the OR and catalyzes the conversion of ATP to cAMP. However, in cyclic nucleotide-gated (CNG) channel knock-out mice OSN axons are only transiently perturbed (Lin et al., 2000), suggesting that the CNG channel may not be the sole target of cAMP. This prompted us to investigate an alternative channel, the hyperpolarization-activated, cyclic nucleotide-gated cation channel (HCN), as a potential developmental target of cAMP in OSNs. Here, we demonstrate that HCN channels are developmentally precocious in OSNs and therefore are plausible candidates for affecting OSN axon development. Inhibition of HCN channels in dissociated OSNs significantly reduced neurite outgrowth. Moreover, in HCN1 knockout mice the formation of glomeruli was delayed in parallel with perturbations of axon organization in the olfactory nerve. These data support the hypothesis that the outgrowth and coalescence of OSN axons is, at least in part, subject to activity-dependent mechanisms mediated via HCN channels.
\end{abstract}

\section{Introduction}

During development, newly generated olfactory sensory neurons (OSNs) extend axons toward the presumptive olfactory bulb (OB) where they form the olfactory nerve layer, segregate in an odorant receptor-specific manner, and coalesce into homogeneous glomeruli. The mechanisms underlying these processes remain poorly understood.

The role of functional activity in OSN axon coalescence and glomerular formation remains controversial (Lin et al., 2000; Zheng et al., 2000; for reviews see Zou et al., 2009; Sakano, 2010). Odorant binding to OSNs initiates a transduction cascade, each step of which could affect cellular activity and axon targeting. When odorants bind to an odorant receptor (OR), the coupled G protein $\alpha$-subunit activates adenylyl cyclase III (ACIII), produc-

\footnotetext{
Received Aug. 12, 2010; revised 0ct. 1, 2010; accepted 0ct. 5, 2010.

This work was funded by National Institutes of Health (NIH)-National Institute on Deafness and Other Communication Disorders and NIH-National Institute on Aging grants (C.A.G.). A.M.M. was supported by Medical Scientist Training Program Grant GM07205 and NIH Grant F30 DC010324. A.S.M. was supported by Neurobiology Training Grant NS 007224-24 and National Research Service Award F32 DC010098-01A1. We thank Drs. L. Rela and M.B. Richard for developing the whole-mount imaging technique in our lab. HCN antibodies were generously provided by Dr. R. Shigemoto, National Institute for Physiological Sciences, Japan.

${ }^{*}$ A.S.M. and A.M.M. contributed equally to this work.

Correspondence should be addressed to Dr. Charles A. Greer, Department of Neurosurgery, Yale University School of Medicine, P.0. Box 208082, New Haven, CT 06520-8082. E-mail: charles.greer@yale.edu.

DOI:10.1523/JNEUROSCI.4225-10.2010

Copyright $\odot 2010$ the authors $\quad 0270-6474 / 10 / 3016498-11 \$ 15.00 / 0$
}

ing cAMP. The cAMP opens cyclic nucleotide-gated (CNG) channels, resulting in a depolarization. In the absence of the CNG $\alpha$-subunit, most odorant-evoked responses are lost (Brunet et al., 1996). However, in mice lacking functional CNG channels the OB has comparatively normal morphology (Lin et al., 2000). In contrast, in ACIII knock-out mice glomerular formation is drastically perturbed (Zou et al., 2007), suggesting that cAMP production is important, but that CNG channels may not be the sole target.

Recently, attention shifted toward mechanisms upstream of the CNG channel and their role in axon guidance. Expression of a constitutively active $\mathrm{G}$ protein or protein kinase A in OSNs changed the location of OR-specific axon convergence, implicating $\mathrm{G}$ protein-mediated cAMP signals in axon convergence (Imai et al., 2006). Chesler et al. (2007) similarly showed that $G$ protein activity was sufficient for axon coalescence, independent of OR expression, with downstream cAMP playing a key role in axonal sorting. Alterations in cAMP production may contribute to the regulation of adhesion molecules mediating axon:axon coalescence (Serizawa et al., 2006).

Alternative cAMP-dependent mechanisms may also be considered. In the hippocampus, the hyperpolarization-activated, cyclic nucleotide-modulated cation channel (HCN) is implicated in developmental mechanisms. HCN channels are heteromers (Chen et al., 2001; Zhou et al., 2004) and how the four HCN subunits combine alters cAMP sensitivity, which determines the 
dynamics of the hyperpolarization-activated current $\left(I_{\mathrm{h}}\right)$, contributing to neuronal excitability (Wainger et al., 2001; Ye and Nerbonne, 2009). In rat hippocampus, HCN subunits are differentially expressed during postnatal development (Brewster et al., 2007); during the first week $I_{h}$ is extremely sensitive to cAMP, with as little as $10 \mathrm{~nm}$ having a significant effect on $I_{\mathrm{h}}$ voltage dependence (Surges et al., 2006). In contrast, in the adult OSN CNG channels are much less sensitive ( $\mathrm{EC}_{50}$ of $\left.4.0 \mu \mathrm{M}\right)$, although measurements from immature OSNs have not been reported (Frings et al., 1992; Zagotta and Siegelbaum, 1996). Nevertheless, the differential expression of HCN subunits and their sensitivity to cAMP in the developing hippocampus compared to the adult suggests an alternative mechanism that may also regulate OSN activity during early development.

Here, we demonstrate precocious $\mathrm{HCN}$ subunit expression in developing OSNs, HCN regulation of neurite extension in vitro, and in $\mathrm{HCN} 1$ mutant mice a perturbation of OSN axonal organization in the $\mathrm{OB}$ nerve layer and dysregulation of glomerular formation. Our data support the hypothesis that HCN-mediated mechanisms are likely candidates in regulating early developmental events in olfactory system formation.

\section{Materials and Methods}

Animals. $\mathrm{HCN1}^{-1-}$ mice (Jackson Laboratories) were bred with C57BL/6 mice (Charles River Laboratories) to obtain heterozygous animals. Heterozygous mice were bred to obtain litters for analysis. $\mathrm{HCN1}{ }^{-1-}$ mice were crossed with M72-GFP C57BL/6J mice to obtain HCN1/M72-GFP heterozygotes (where GFP is green fluorescent protein). The heterozygotes were bred to obtain $\mathrm{HCN} 1^{+/+} / \mathrm{M} 72-\mathrm{GFP}$ homozygotes and HCN1 ${ }^{-1-} / \mathrm{M} 72-$ GFP homozygotes for analysis. Tail tips were taken to confirm genotype with PCR. For embryonic mice, timed pregnant females (day of the vaginal plug $=$ embryonic day 0 ) were killed using $\mathrm{CO}_{2}$, followed by cervical dislocation. Embryonic and postnatal pups were swiftly decapitated and placed in $4 \%$ paraformaldehyde (PFA) in $0.1 \mathrm{M}$ PBS overnight. Mice older than postnatal day (P) 7 were anesthetized with pentobarbital and perfused transcardially with $0.1 \mathrm{M}$ PBS with $1 \mathrm{U} / \mathrm{ml}$ heparin followed by $4 \%$ PFA and $2 \mathrm{~h}$ postfixation in $4 \% \mathrm{PFA}$, followed by $0.1 \mathrm{M}$ PBS overnight. Mice required for RNA or protein (CD1; Charles River Laboratories) were asphyxiated with $\mathrm{CO}_{2}$ gas and decapitated. OB and olfactory epithelium (OE) were dissected out separately. Tissue for protein was frozen immediately. Tissue for reverse transcriptase (RT)-PCR was frozen in $1 \mathrm{ml}$ of TRIzol per $100 \mathrm{mg}$ of tissue. B6129SF2/J mice (Jackson Laboratories) were bred to obtain litters for primary tissue culture. Mice were housed in the Yale Animal Facility (New Haven, CT) and their care and use was approved by the Yale University Animal Care and Use Committee.

Electrophysiology. OEs were isolated from 3- to 4-week-old C57BL/6 male and female mice using a modification of protocols described previously (Bozza and Kauer, 1998). Briefly, mice were deeply anesthetized with isoflurane and decapitated. The head was opened sagittally, and the septum was removed to expose the medial surface of the olfactory turbinates. The OE was dissected out and placed in an oxygenated, divalentfree Ringer solution containing the following (in $\mathrm{mm}$ ): $145 \mathrm{NaCl}, 5.6 \mathrm{KCl}$, 10 HEPES, 10 D-glucose, 4 EGTA, pH 7.4. The tissue was finely cut and incubated for $10-15 \mathrm{~min}$ at $37^{\circ} \mathrm{C}$ in $3 \mathrm{ml}$ of divalent-free Ringer solution containing 10-20 U/ml papain and $4 \mathrm{~mm} \mathrm{~L}$-cysteine (Sigma Aldrich). The tissue was then transferred to a normal Ringer solution containing the following (in mM): $138 \mathrm{NaCl}, 5 \mathrm{KCl}, 1 \mathrm{CaCl}_{2}, 1.5 \mathrm{MgCl}_{2}, 10 \mathrm{HEPES}$, $10 \mathrm{D}$-glucose, $\mathrm{pH} 7.4$, containing $10 \mu \mathrm{g} / \mathrm{ml}$ leupeptin and gently dissociated using a fire-polished Pasteur pipette. Dissociated OSNs were directly plated onto the glass bottom of a perfusion chamber mounted directly on an upright Olympus BX51 microscope, and the cells were allowed to settle for $20 \mathrm{~min}$.

Voltage-clamp experiments were conducted using a dual EPC10 amplifier (HEKA). For recording we used standard patch pipettes with resistance of 5-10 M $\Omega$ when filled with an internal solution of the following composition (in mM): $125 \mathrm{KF}, 15 \mathrm{KCl}, 11 \mathrm{EGTA}, 3 \mathrm{MgCl}_{2}, 10$
HEPES, 5 tetraethylammonium, $4 \mathrm{Na}$-ATP, adjusted to $\mathrm{pH} 7.3$ with $\mathrm{KOH}$. The osmolarity of the internal solutions was adjusted to 290-305 mOsm. ZD 7288 (Tocris Bioscience) was prepared from a stock solution and bath applied for at least $3 \mathrm{~min}$. We recorded from cells that had the characteristic morphology of OSNs (i.e., dendrite and cilia) (see Fig. $1 \mathrm{~A}$ ). Only recordings from cells that exhibited inward and outward currents at depolarized potentials were included in the analysis. Data analysis was performed using the Patcher's Power Tools (PPT) written for the IGOR Pro software (WaveMetrics). Cells were held at $-60 \mathrm{mV}$ and the peak current was measured within the last $10 \mathrm{~ms}$ of the hyperpolarizing step. The normalized whole-cell conductance $\left(G / G_{\max }\right)$ was fitted using the Boltzmann equation as described in the PPT macros.

RT-PCR. OE from CD1 mice at embryonic day (E) 13, E15, E17, P0, and $\mathrm{P} 4$ was extracted using sterile technique, placed in $1 \mathrm{ml}$ of TRIzol (Invitrogen) for each $100 \mathrm{mg}$ of tissue, and homogenized. RNA was purified from the tissue following the TRIzol protocol. Contaminating DNA was removed using TURBO DNA-free (Ambion). Synthesis of cDNA was completed using the SuperScript III First Strand kit (Invitrogen). The DNA gene sequences published on National Center for Biotechnology Information (NCBI) for HCN1, HCN2, and HCN4 were analyzed using PerlPrimer free software to select primers that were verified in NCBI/BLAST (basic local alignment search tool) for sequence matches. A primer to $\beta$-actin was used as a control for RT-PCR and gel loading. Primers for each gene of interest were combined with mouse cDNA for PCR along with controls for each cDNA source made without the reverse transcriptase enzyme. The primers were as follows: HCN1 forward primer, 5'-GAAATGGTTAATGATTCCTGGG-3'; HCN1 reverse primer, 3'-CGAAAGGGAGTAAAGACGAC-5'; HCN2 forward primer, 5'-GACTTCAGGTTCTACTGGGAC-3'; HCN2 reverse primer, 3'-CATGTTGTTGATGGACACCC-5'; HCN4 forward primer, 5'-GCAAGATGTTTGATGAGGA-3'; HCN4 reverse primer, 3'-ATGTGGAAGGAGGATGAAGAC-5'; actin forward primer, 5'-GTGGGCCGCTCTAGGCACCAA-3'; actin reverse primer, $3^{\prime}$-CTCTTTGATGTCACGCACGATTTC-5'. Primers combined with cDNA and PlatinumBlue PCR Supermix (Invitrogen;) were annealed at $53^{\circ} \mathrm{C}$, transcribed at $72^{\circ} \mathrm{C}$ and repeated 30 times for amplification. PCR product was run on agarose gels [ $2 \%$ agarose in $1 \times$ TAE $(0.04 \mathrm{M}$ Tris, $0.004 \mathrm{M}$ acetate, 0.001 м EDTA)].

For genotyping $\mathrm{HCN} 1$ heterozygous litters, tails were digested in 50 $\mathrm{mm} \mathrm{NaOH}$ for $1 \mathrm{~h}$ at $100^{\circ} \mathrm{C}$. Digestion was stopped by adding Tris- $\mathrm{HCl}$, and the DNA was combined with primer sequences obtained from The Jackson Laboratory.

Quantitative Western blots. Freshly dissected OE was homogenized in lysis buffer $[1 \times$ Complete protease inhibitor cocktail tablet (Roche, $1 \mathrm{~mm}$ EDTA, pH 8, 1\% SDS, 10 mm Tris-Cl, pH 7.4), sonicated on ice for 10 $\mathrm{min}$, ground with a pestle for $1 \mathrm{~min}$, and incubated for $5 \mathrm{~min}$ at $100^{\circ} \mathrm{C}$. Protein concentration was determined by Bradford assay using Coomassie Plus protein assay reagent (Thermo Scientific) measured in a Gene Quant Pro spectrophotometer (GE Healthcare). Equal quantities of each protein sample were boiled in Laemelli buffer (67.5 mu Tris- $\mathrm{HCl}$ pH 7.4, $2.3 \%$ SDS, $10 \%$ glycerol, $5 \% \beta$-mercaptoethanol, $0.017 \%$ bromophenol blue), at $70^{\circ} \mathrm{C}$ for $10 \mathrm{~min}$, resolved using $4-15 \%$ SDS-PAGE (Bio-Rad), and transferred to nitrocellulose membranes (Bio-Rad). Membranes were incubated at room temperature for $1 \mathrm{~h}$ in a blocking buffer containing $5 \%$ nonfat powdered milk, $2.5 \%$ BSA in TBS-T (100 mM Tris-Cl, $\mathrm{pH}$ $7.4,150 \mathrm{~mm}$ sodium chloride, $0.3 \%$ Tween 20 ), followed by incubation with either rabbit anti-HCN1 (Millipore), guinea pig anti-HCN2 (generous gift from Dr. Ryuichi Shigemoto, National Institute for Physiological Sciences, Myodaiji, Japan), rat anti-HCN4 (Abcam), or mouse anti- $\beta$-actin (Abcam) in blocking buffer and kept at $4^{\circ} \mathrm{C}$ overnight. After washing with $5 \%$ nonfat powdered milk in TBS-T, the membranes were incubated with horseradish peroxidase-conjugated secondary antibody (Jackson ImmunoResearch) for $1 \mathrm{~h}$ at room temperature. Immunoreactive bands were detected by ECL Western blotting detection reagents (GE Healthcare). Molecular weights were determined using BenchMark prestained protein ladder (Invitrogen). Re-Blot Plus-Strong (Millipore) was used for stripping antibodies from a membrane. ImageJ gel analyzer tool (National Institutes of Health, Bethesda, MD; http://rsb.info.nih.gov/ij/) was used to integrate the signal measured from scanned images of the film to determine the ratio of $\mathrm{HCN}$ to $\beta$-actin in each lane. 
Primary cell cultures. Eight-well culture slides were coated with $50 \mu \mathrm{M}$ poly-D-lysine for $1 \mathrm{~h}$ then rinsed with distilled $\mathrm{H}_{2} \mathrm{O}$. $\mathrm{P} 1-\mathrm{P} 2$ pups were killed by decapitation; the $\mathrm{OE}$ was removed from the septum in HBSS (Invitrogen). Tissue was dissociated using the Worthington papain dissociation kit (Worthington Biochemical) for $1 \mathrm{~h}$ at $37^{\circ} \mathrm{C}$ in a $5 \% \mathrm{CO}_{2}$ incubator. After trituration using a fire-polished glass pipette, dissociated cells were separated from fragments of $\mathrm{OE}$ using a gradient (Worthington papain kit), plated in Neurobasal media (Invitrogen), and grown for $24 \mathrm{~h}$ at $37^{\circ} \mathrm{C}$ in $5 \%$ $\mathrm{CO}_{2}$. Drugs (1-20 $\mu \mathrm{M}$ loperamide or $5-30 \mu \mathrm{M}$ ZD7288) were added to the cells and allowed to incubate another $24 \mathrm{~h}$, followed by fixation with $4 \%$ PFA in $4 \%$ sucrose twice for $15 \mathrm{~min}$. Immunohistochemistry was performed as described below with primary antibody rat antineuronal cell adhesion molecule (NCAM) (1: 500; Millipore), Alexa Fluor 488 phalloidin (Invitrogen), and the nuclear marker DRAQ5 (1:500; Biostatus). Cell measurements were obtained using HCA-Vision, V1.7.3 (CSIRO Biotech Imaging).

Immunohistochemistry. Fixed tissue was cryoprotected in $30 \%$ sucrose in $0.1 \mathrm{M}$ PBS overnight and then transferred to OCT, rapidly frozen in a slurry of dry ice and ethanol, and stored at $-80^{\circ} \mathrm{C}$ until used. Serial sections $(20$ $\mu \mathrm{m}$ thick) of the $\mathrm{OE}$ and $\mathrm{OB}$ were collected on Superfrost Plus slides (VWR) and stored at $-20^{\circ} \mathrm{C}$ until used. Slides were heated to $37^{\circ} \mathrm{C}$

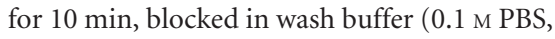
2\% BSA, $0.3 \%$ Triton $\mathrm{X}-100$ ) for $30 \mathrm{~min}$, and incubated in the following primary antibodies at $4^{\circ} \mathrm{C}$ overnight; chicken antibody: anti-MAP-2 at 1:1000 (Millipore); rabbit antibodies: ACIII at 1:250 (Santa Cruz Biotechnology), growthassociated protein 43 (GAP43) at 1:1000 (Novus), HCN1 at 1:250, peripherin at 1:2000 (Millipore), olfactory cell adhesion molecule (OCAM) 1:500 (generous gift from Dr. Yoshihiro Yoshihara, RIKEN Brain Science Institute, Wako, Japan), and vesicular glutamate transporter 2 (VGlut2) at 1:2000 (Synaptic Systems); rat antibodies: HCN4 at 1:500 (Abcam), HCN4 at 1:1000 (Alomone) and NCAM at 1:1000 (Millipore); goat antibodies: olfactory marker protein (OMP) at 1:1000 (Wako Pure Chemical Industries) and neuropilin 1 (Nrp1) at 1:750 (R\&D Systems); guinea pig anti-HCN2 at 1:1000 (generous gift from Dr. Ryuichi Shigemoto); rabbit anti-HCN2 (HCN2 $\beta$ ); and guinea pig antiHCN4 (HCN4 $\gamma$ ) (F.M.). After rinsing in wash buffer, slides were incubated with fluorescent secondary antibodies (donkey anti-rabbit Alexa Fluor 488 or Alexa Fluor 555; donkey anti-rat Alexa 594; donkey anti-goat Alexa Fluor 488 or Alexa Fluor 555; donkey anti-guinea pig Alexa 488; all used at 1:1000 and all from Invitrogen) and nuclear stain DRAQ5 at 1:1000 (Biostatus) for $1 \mathrm{~h}$ at room temperature, rinsed and coverslipped with BioMeda GelMount (Electron Microscopy Sciences).

Imaging. Cell culture images were captured on an Olympus BX51 fluorescent scope and camera. All other images were taken as single plane images on a Leica confocal microscope except for the images in Figure 10, which are $z$-stacks. Image brightness, contrast, or levels were adjusted using Photoshop CS (Adobe Systems) but not altered or manipulated. Image plates were constructed using CorelDRAW 12 (Corel) or Adobe Illustrator CS2 (Adobe Systems). For whole mount confocal imaging, fixed P10 brains from HCN $1^{-/-} / \mathrm{M} 72-\mathrm{GFP}$ or $\mathrm{HCN} 1^{+/+} /$ M72-GFP mice were embedded in $2 \%$ agarose for stability without covering the dorsal OB surface. A $40 \times$ water-immersion objective in $0.1 \mathrm{M}$ phosphate buffer was used to scan each $\mathrm{M} 72^{+}$glomerulus using $0.5 \mu \mathrm{m} z$-steps.

Olfactory bulb measurements. Glomerular area was determined by outlining the glomeruli and using the Measure and Label Plugin in ImageJ.
B

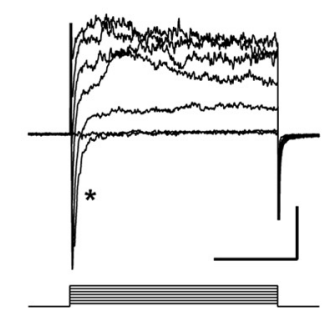

E

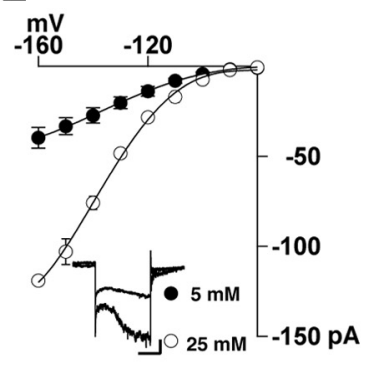

C

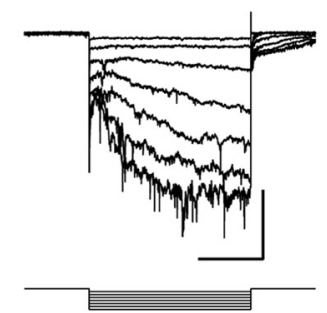

$\mathbf{F}$

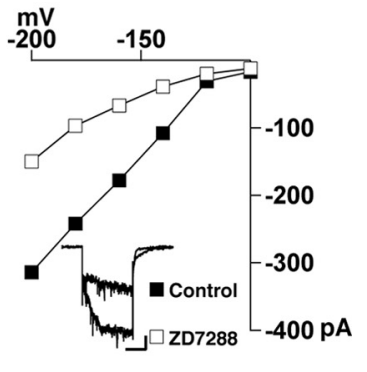

Figure 1. Hyperpolarization-activated inward currents in dissociated mouse OSNs. $A$, Whole-cell recording in an acutely dissociated OSN; the arrow points to protruding cilia from the dendritic knob. B, Cells exhibit characteristic fast inward (asterisk) and late currents elicited by depolarizing steps (20 mV increments). C, Hyperpolarization-activated currents were elicited by con $\mathrm{K}^{+}$was increased. The inset shows currents obtained with a hyperpolarizing step to $-160 \mathrm{mV}$ (filled circles, 5 ZD7288). The holding potential is $-60 \mathrm{mV}$. The calibration bar is $20 \mathrm{~ms}$ and $100 \mathrm{pA} \mathrm{for} \boldsymbol{B}, 200 \mathrm{~ms}$ and $100 \mathrm{pA} \mathrm{for} \mathrm{C,} 100 \mathrm{~ms}$ and 100 pA for the inset in $E, 100 \mathrm{~ms}$ and $20 \mathrm{pA}$ for the inset in $\boldsymbol{F}$.

Glomeruli were outlined based on VGlut2 and NCAM labeling from matched rostral, intermediate, and caudal sections of the OBs from $\mathrm{HCN}^{-1-}$ and wild-type (WT) littermates. The number of glomeruli outlined was summed across sections. Regional distribution was determined by placing two lines crossing at $90^{\circ}$ angles over the OB image. A linear aggregate index was compiled by placing $20^{\circ}$ divisions centered over an OB image. The number of glomeruli crossed by each division line was counted. Images of OSN axons, labeled with NCAM and peripherin, were compared by placing $60^{\circ}$ divisions centered over an OB image. Where the division line crossed the nerve layer, the intensity ratio of peripherin:NCAM were measured at $10 \%$ increments in a line perpendicular to the mitral cell layer using the ImageJ Plot Profile tool. The average of the means from the last two measurements (90, 100\%) was compared to determine significance. For wholemount measurements, fixed P10 M72-GFP brains embedded in 2\% agarose were imaged at $4 \times$ under an Olympus BX51 fluorescent scope and camera. Images were analyzed using the ImageJ Measure and Label plugin and the Analyze/ Measure feature. First, a line was drawn between the OBs and the cortex. Next, a line perpendicular to the first line was drawn between the OBs. The point where the two lines crossed is referred to as the intersect point. Medial angles are defined as the angle from the intersect point to the medial glomerulus to the contralateral medial glomerulus. Lateral angles are defined as the angles from the ipsilateral medial glomerulus to the lateral glomerulus to the contralateral lateral glomerulus. Distances were measured by drawing a line between the ipsilateral lateral and medial glomeruli or medial to medial glomeruli.

To determine the distance from the beginning of the accessory olfactory bulb (AOB) to the M72-GFP glomerulus, consecutive $20 \mu \mathrm{m} \mathrm{sec}-$ tions from $\mathrm{P} 21$ fixed, frozen OBs were stained with rat anti-NCAM (1: 1000; Invitrogen). P14 WT or $\mathrm{HCN}^{-1-}$ mice were stained with NCAM and rabbit anti-MOR28 (generous gift from Dr. Richard Axel, Columbia University, New York). The number of sections between each of the four M72-GFP or MOR28 glomeruli to the first section showing 
AOB was counted to determine the distance (number of sections multiplied by $20 \mu \mathrm{m})$.

\section{Results}

Acutely dissociated mouse olfactory sensory neurons exhibited characteristic morphology, including an intact dendrite from which cilia extended (Fig. 1A). Depolarizing steps from $-60 \mathrm{mV}$ elicited a fast inward and a slow outward current (Fig. $1 B$ ). These currents were previously described in OSNs, correspond to $\mathrm{Na}^{+}$and $\mathrm{K}^{+}$ currents, and need not be described further here (Lagostena and Menini, 2003). More importantly, hyperpolarizing steps (250-500 $\mathrm{ms}$ ) induced a slowly activating inward current (Fig. 1C). The maximal current at $-160 \mathrm{mV}$ was $-39.7 \pm 5.8 \mathrm{pA}(n=10)$. The normalized conductance was maximal at membrane potentials more negative than $-160 \mathrm{mV}$ and could be fitted to a Boltzmann distribution with a $\mathrm{V}_{1 / 2}=-130 \pm 10 \mathrm{mV}$ and a slope factor of $16 \pm 4 \mathrm{mV}$ $(n=3)$ (Fig. 1D). The hyperpolarization-activated inward current was larger when the extracellular concentration of $\mathrm{K}^{+}$was increased; in $25 \mathrm{mM} \mathrm{K}^{+}$the inward current was $-119 \pm 3 \mathrm{pA}(n=3 ;-160$ $\mathrm{mV}$ ) (Fig. $1 E$ ). Furthermore, the selective HCN inhibitor ZD7288 $(30 \mu \mathrm{M})$ significantly reduced the current by $45 \pm 11 \%(-200 \mathrm{mV}$; $p<0.02 ; n=4)($ Fig. $1 F)$. Together, these results are consistent with a hyperpolarization-activated current, $I_{\mathrm{h}}$, in mouse OSNs. The properties of the mouse OSN $I_{\mathrm{h}}$ are similar to those described previously in rat OSNs and mouse vomeronasal sensory neurons (Lynch and Barry, 1991; Vargas and Lucero, 1999; Dibattista et al., 2008).

To determine the developmental pattern of HCN channels in mice, we first assessed mRNA expression at time points chosen for their significance within the developmental timeline of the olfactory system (Treloar et al., 2009). At embryonic day E13 OSN axons are sorting and contacting the presumptive OB. By E15 axons are growing into the dendritic zone of the $\mathrm{OB}$, and by E17 protoglomeruli are emerging. At postnatal day P0 small discrete glomeruli can be seen. By $\mathrm{P} 4$ the glomeruli are larger in size and more mature. We focused our study on the HCN subunits reported to have increased kinetics or amplitude in the presence of cAMP: HCN1, HCN2, and HCN4 (Chen et al., 2001; Surges et al., 2006). At each time point, primers specific to each subunit demonstrated mRNA expression of HCN1, HCN2, and HCN4 in the OE (Fig. 2A).

We confirmed that the $\mathrm{HCN}$ channel subunit proteins were present in the $\mathrm{OE}$ using immunoblots. $\mathrm{HCN} 1, \mathrm{HCN} 2$, and $\mathrm{HCN} 4$ are all expressed in the OE at E13, E17, and P4 (Fig. 2 B). We identified the unglycosylated $102 \mathrm{kDa}$ form of $\mathrm{HCN} 1$, the glycosylated $108 \mathrm{kDa}$ form of HCN2, and the unglycosylated $132 \mathrm{kDa}$ form of $\mathrm{HCN} 4$, as previously reported in retina (Müller et al., 2003). In the hippocampus, each HCN subunit has a unique developmental pattern of expression. For example, HCN4 is implicated in early developmental events, but was down regulated at later stages, reflecting kinetic properties of the neurons (Surges et al., 2006). Interestingly, in the OE, HCN2 levels increased significantly between E13 and P4 (Fig. 2C), suggesting that the kinetics of the OSN HCN channel may change during this timeframe, perhaps due to ongoing developmental events. Quantitative analysis showed that there were no significant developmental changes in $\mathrm{HCN} 1$ or HCN4 subunit expression (Fig. 2C).

The pseudostratified mature $\mathrm{OE}$ consists, from apical to basal, of a layer of sustentacular cells, mature OSNs, immature OSNs, and horizontal and basal cells. We used immunohistochemistry to identify which cell types in the OE expressed HCN channels throughout development. At E13 HCN1, HCN2, and HCN4 colocalize with GAP43, a marker of immature OSNs, throughout the OE (Fig. $3 A-A^{\prime \prime}$ ). By E15, colocalization of GAP43 and the
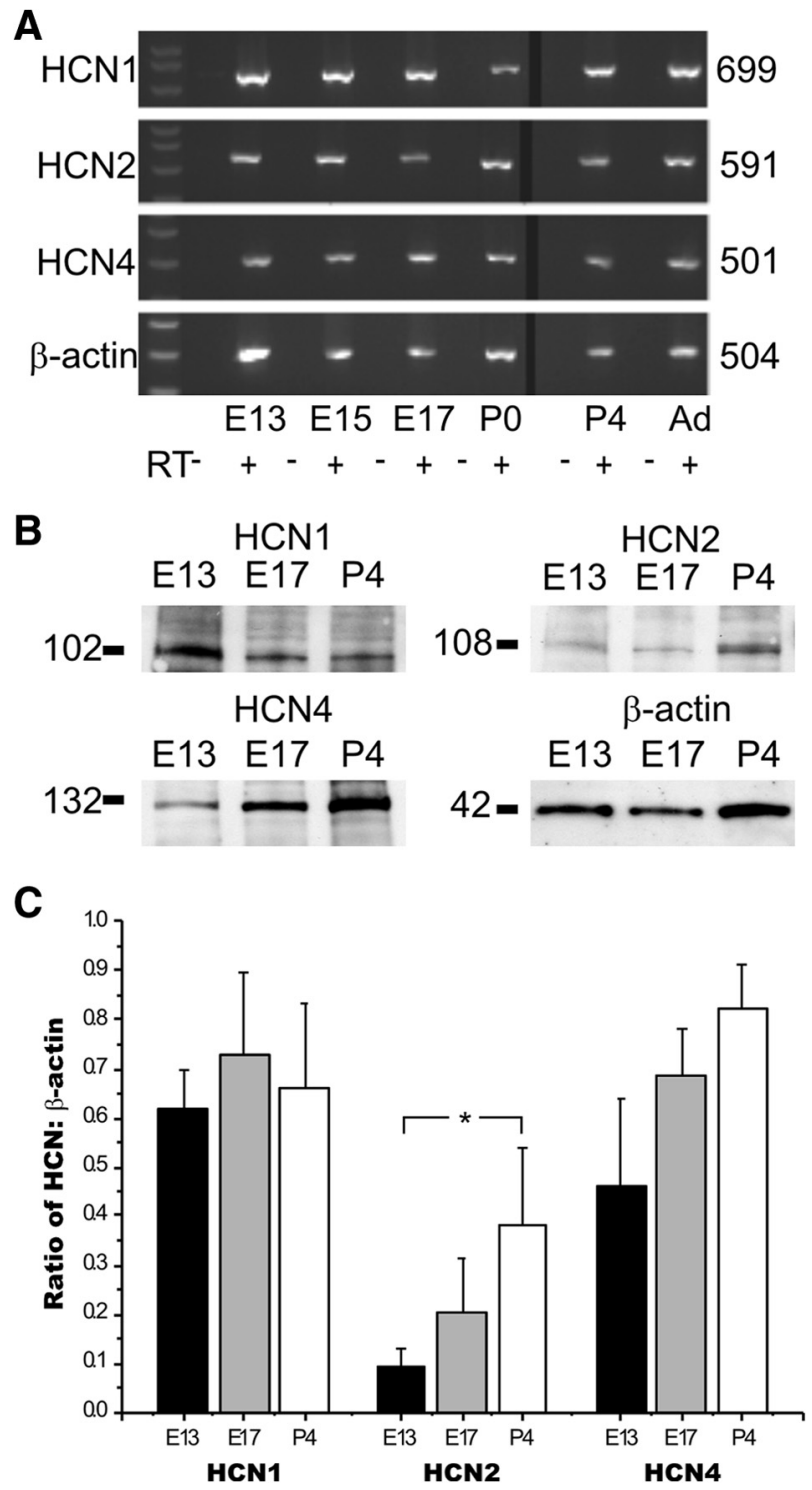

Figure 2. HCNs are present in the OE during the early development of the olfactory system. $A, \mathrm{RT}-\mathrm{PCR}$ from mouse $\mathrm{OE}$ for HCN1, 2, and 4. Numbers to the right are nucleotide length. Ad, Adult. $\boldsymbol{B}$, Western blots from mouse OE. Numbers to the left are molecular weights. C, Quantification of protein levels across embryonic development for each HCN subunit. Asterisk indicates $p<0.05$. Error bars, SEM.

HCN subunits was restricted to the basal (immature) half of the OE (data not shown). At E17, HCN subunit expression became more prominent in the apical (mature) layer of the OE and by P2 no longer showed robust colocalization with GAP43, except within the axons (Fig. 3B- $B^{\prime \prime}$; supplemental Figs. 1, 2, available at www.jneurosci.org as supplemental material). Double-labeling with OMP, a marker of mature OSNs, showed that at P2 HCN channel subunit expression was limited to mature OSNs (Fig. $\left.3 C-C^{\prime \prime}\right)$. There was no evidence of HCN expression in the sustentacular cells or basal cells. We did not find evidence of $\mathrm{HCN}$ subunit segregation in different cell populations within the $\mathrm{OE}$. $\mathrm{HCN}$ channel subunit expression was homogeneous in mature OSNs across the OE (Fig. 4). Interestingly, beginning at E13 and at all ages examined, HCN channel subunits colocalized with ACIII. For example, even at E15 when very few cells express ACIII, all ACIII ${ }^{+}$cells were $\mathrm{HCN}^{+}$, suggesting that $\mathrm{HCN}$ channels are expressed in cells that include functional members of the 
cAMP pathway (supplemental Fig. 3, available at www.jneurosci.org as supplemental material).

Functional activity is repeatedly implicated as an important determinant in the extension and arborization of axons (Williams and Cohan, 1995; Zhao and Reed, 2001; Hanson and Landmesser, 2004; Yu et al., 2004; Singh and Miller, 2005; Zou et al., 2007). To determine whether $I_{\mathrm{h}}$ influences OSN neurite extension, as implied by its early expression in developing OSNs, we cultured primary dissociated OSNs from P1-P2 CD1 mice in the presence or absence of two different HCN channel inhibitors and measured the effect on neurite outgrowth and branching. Cultured OSNs were immunoreactive for the neuronal marker NCAM, the OSN markers OMP and ACIII (supplemental Fig. 4, available at www.jneurosci.org as supplemental material), and the $\mathrm{HCN}$ channel subunits (Fig. 5A-C). In the presence of either 5-30 $\mu \mathrm{M}$ ZD7288 or $1-20 \mu \mathrm{M}$ loperamide, two $\mathrm{HCN}$ channel inhibitors (Gasparini and DiFrancesco, 1997; Vasilyev et al., 2007; Lee et al., 2008), we found a significant dose-dependent decrease in both total neurite outgrowth and branching (Fig. $5 H-M)$. Control experiments with loperamide's diluent, methanol, did not affect neurite outgrowth or branching (data not shown).

The growth cone is a dynamic, actinsupported extension of the developing axon with a unique morphology characterized by filopodia and lamellipodia. As shown in Figure 5, D-G, growth cones in loperamide-treated cultures appeared collapsed while those in controls appeared broadly spread, suggesting an "active" profile. These data support the hypothesis that HCN channels are necessary for normal axon outgrowth and branching, as well as maintaining a mature growth cone.

To test in vivo the effects of HCN channels on OSN axon behavior and targeting to the $\mathrm{OB}$, we acquired the HCN1targeted mutant mice in which the exon encoding the $\mathrm{p}$ region and S6 transmembrane (pore-S6) domain was deleted using the loxP system. We hypothesized that in the absence of HCN1, the subunit with the fastest kinetics (Wainger et al., 2001; Surges et al., 2006), cAMP-dependent activity would be altered in the OSNs, resulting in developmental errors. We first repeated our in vitro assay of neurite outgrowth in primary cultures of OSNs from the $\mathrm{HCN} 1$ mutant mice $\left(\mathrm{HCN1}^{-1-}\right)$ and their controls (B6129SF/2). As seen in Figure 6, total neurite length in the $\mathrm{HCN} 1^{-1-}$ mice relative to the $\mathrm{B} 6129 \mathrm{SF} / 2$ controls is reduced. Scale bar, $25 \mu \mathrm{m}$ (in $\boldsymbol{A}$ ).
E13
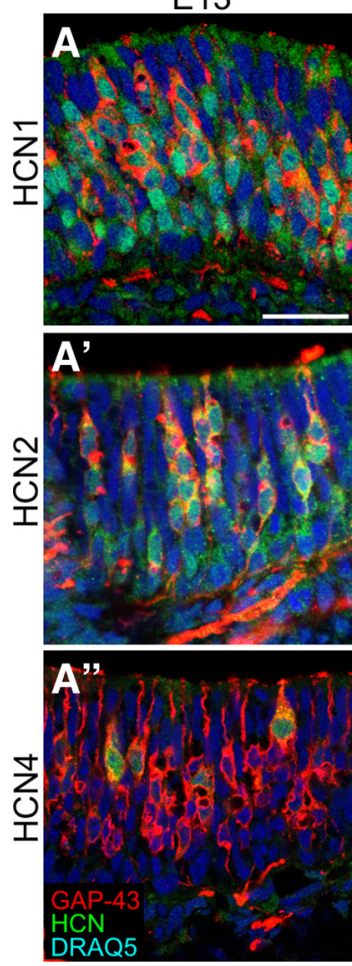

P2
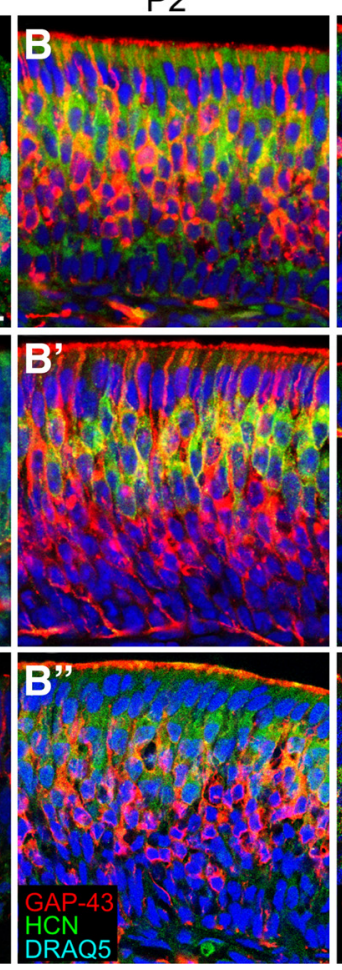

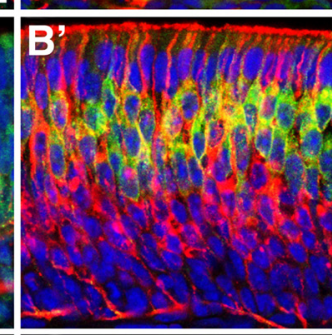

P2
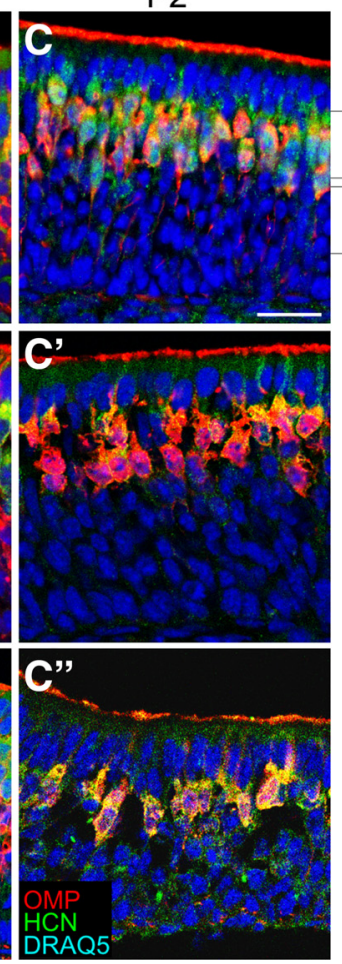

Mature OSNs

Immature OSNs
Figure 3. HCN subunits are present in immature, developing OSNs at E13 and colocalize with GAP43. At P2, some colocalization (yellow) with GAP43 persists with $\mathrm{HCN} 2$ and $\mathrm{HCN} 1$. However, primarily $\mathrm{HCN}$ and $0 \mathrm{MP}$ are coexpressed in the mature OSNs $\left(\mathrm{OMP}^{+}\right)$ which are located apically in the epithelium. $\boldsymbol{A}-\boldsymbol{A}^{\prime \prime}$, E13; GAP-43. $\boldsymbol{B}-\boldsymbol{B}^{\prime \prime}$, P2; GAP-43. $\boldsymbol{C}-\boldsymbol{C}^{\prime \prime}$, P2; 0MP. $\boldsymbol{A}-\boldsymbol{C}, \mathrm{HCN} 1$. $\boldsymbol{A}^{\prime}-\boldsymbol{C}^{\prime}, \mathrm{HCN} 2$. $\boldsymbol{A}^{\prime \prime}-\boldsymbol{C}^{\prime \prime}$, HCN4. Scale bars, $25 \mu \mathrm{m}$; scale bar in $\boldsymbol{A}$ applies to $\boldsymbol{A}-\boldsymbol{B}^{\prime \prime}$; scale bar in $\boldsymbol{C}$ applies to $\boldsymbol{C}^{-\boldsymbol{C}^{\prime \prime}}$.
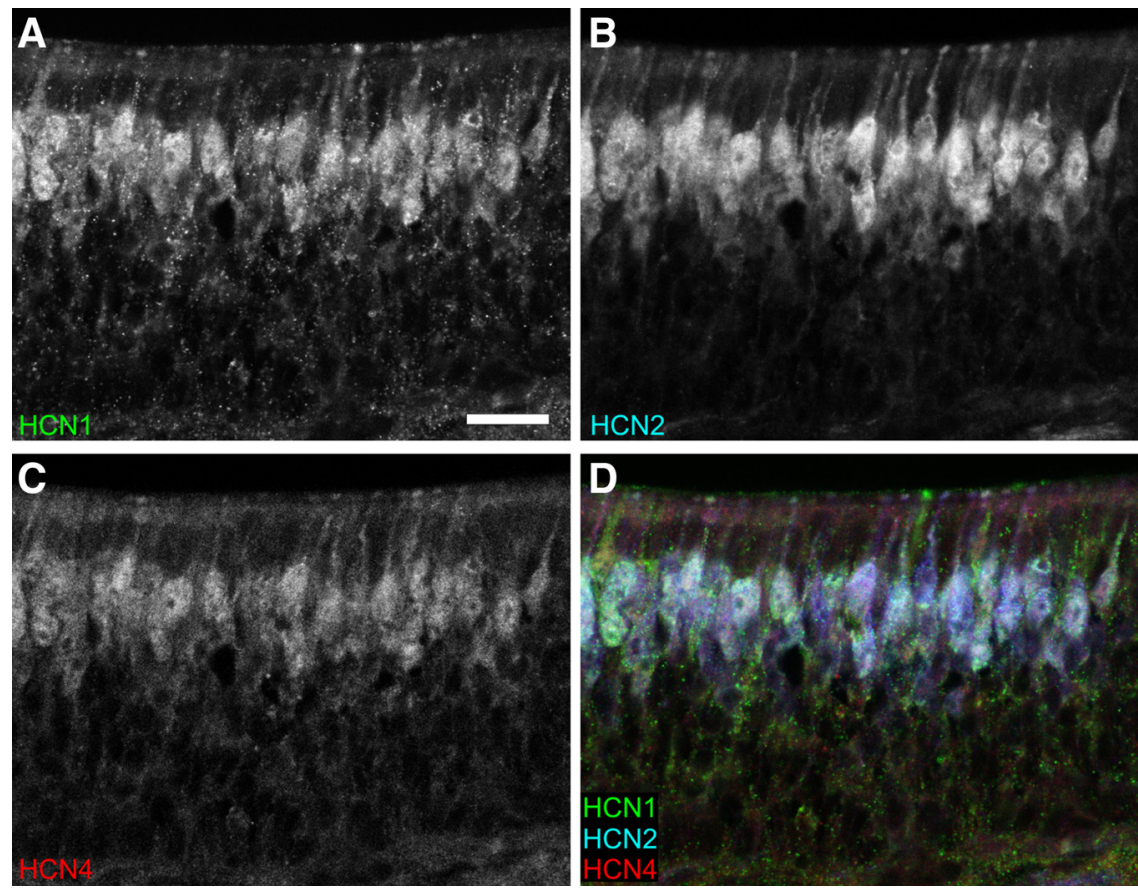

Figure 4. HCN subunits are coexpressed in OSNs at P2. A, HCN1 (green). B, HCN2 (blue). C, HCN4 (red). D, RGB image of $\boldsymbol{A}-\boldsymbol{C}$.

Loperamide $(20 \mu \mathrm{M})$ or ZD7288 $(30 \mu \mathrm{M})$ further reduced neurite outgrowth in the $\mathrm{HCN1}^{-1-}$ mice (36\% reduction) to levels similar to those of controls ( $46 \%$ reduction). The decreased neurite outgrowth in the $\mathrm{HCN}^{-1-}$ mice relative to controls and its 

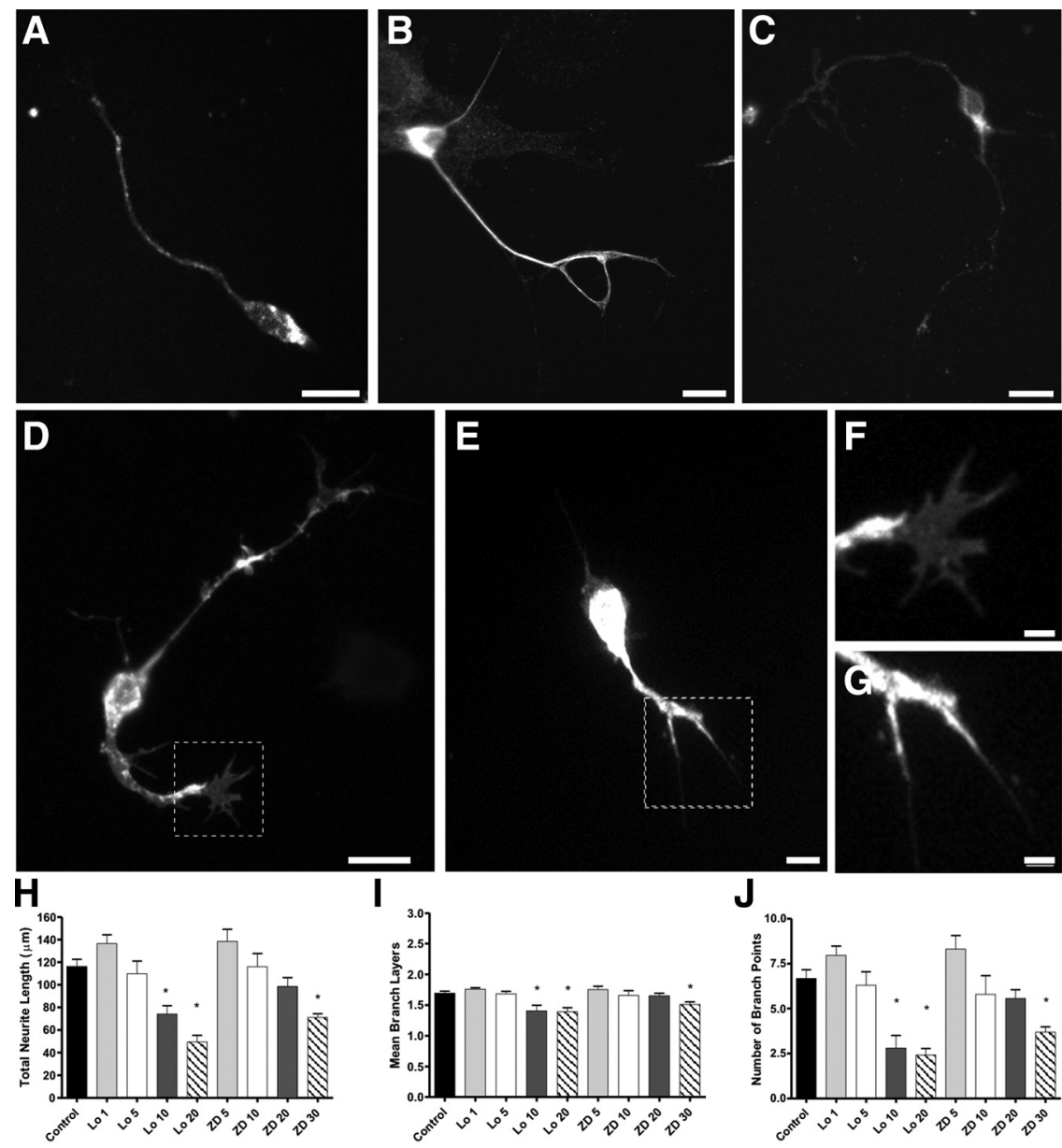

I
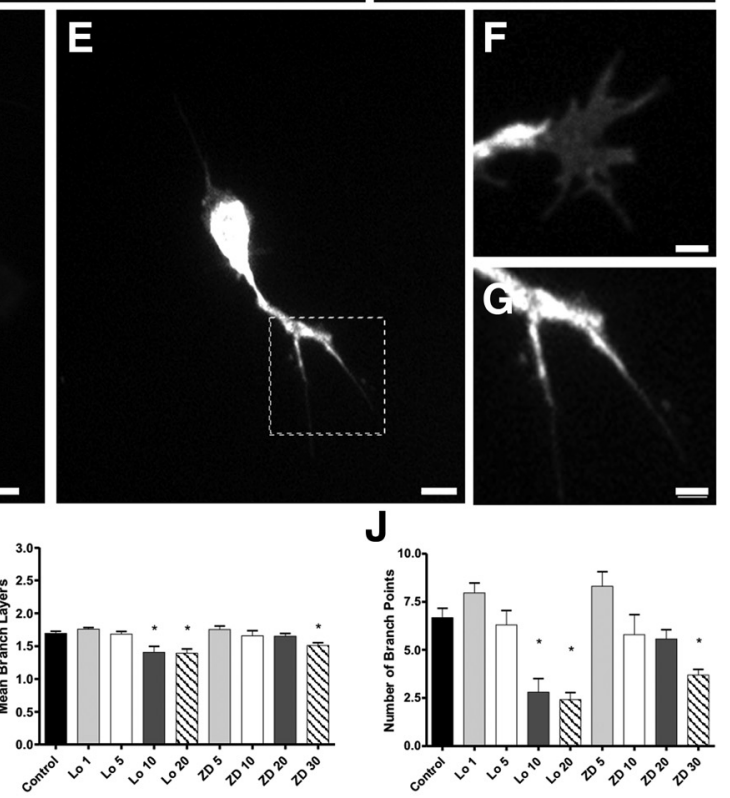

$\mathbf{K}$

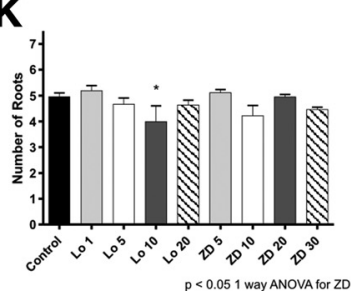

M

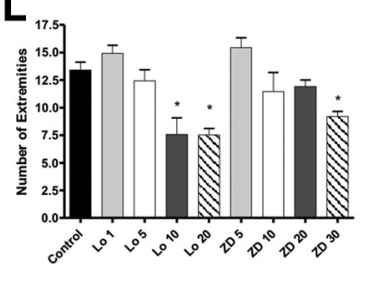

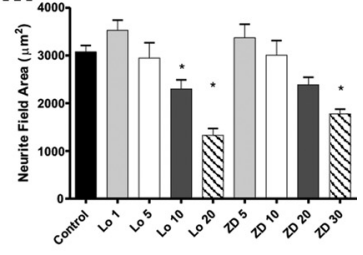

Figure 5. HCNs are present in cultured primary OSNs. Incubation with the $H C N$ channel blocker loperamide or ZD7288 reduces neurite outgrowth and branching. $\boldsymbol{A}-\boldsymbol{C}$, Cultured primary OSNs labeled with HCN1 (A), HCN2 (B), and HCN4 (C). D-G, Primary cultured OSNs labeled with NCAM. D, OSNs cultured in control conditions. $\boldsymbol{E}$, OSNs cultured with $20 \mu \mathrm{m}$ loperamide. $\boldsymbol{F}-\boldsymbol{G}$, High magnification of boxed areas in $\boldsymbol{D}$ and $\boldsymbol{E}$, respectively. $\boldsymbol{H}$, Total neurite length (all neurite segments). $\boldsymbol{I}$, Number of mean branch layers $\left(1^{\circ}, 2^{\circ}\right.$, or $3^{\circ}$ neurites). $\boldsymbol{J}$, Number of branch points. $\boldsymbol{K}$, Number of neurite roots. $\boldsymbol{L}$, Number of extremities. $\boldsymbol{M}$, Neurite field area. Scale bars: $\boldsymbol{A}-\boldsymbol{E}, 10 \mu \mathrm{m} ; \boldsymbol{F}, \boldsymbol{G}, 2 \mu \mathrm{m}$. Error bars, SEM. ${ }^{*} p<0.05$, statistically significant difference from controls.

mutual reduction in response to $\mathrm{HCN}$ channel blockers are consistent with the findings in the CD1 mice and support the hypothesis that HCN channels contribute to OSN neurite outgrowth.

Based on our data from in vitro dissociated OSNs derived from the $\mathrm{HCN}^{-/-}$mice (Fig. 6), we predicted that there would be aberrations in the organization of OSN axons and their coalescence in vivo. To assess glomeruli we used double labeling for NCAM, which ubiquitously labels OSN axons, and VGlut2, which labels the OSN axon glomerular synapses. Indeed, glomerular formation in the $\mathrm{HCN} 1^{-1-}$ mice was developmentally retarded. At E17 the formation of protoglomeruli in the $\mathrm{HCN} 1^{-1-}$ was delayed relative to WT littermate controls (Fig. $7 A, B)$. In the $\mathrm{HCN}^{-/-}$mice, VGlut2-positive axons in the glomerular layer appeared reduced, and there were fewer defined protoglomeruli. As is evident in Figure 7, in controls the spherical protoglomeruli are easily distinguished from the overlying nerve layer. In the $\mathrm{HCN}^{-1-}$ mice, however, the VGlut2 staining is irregular and sparse, with little evidence of protoglomerular formations. By P4, well delineated and mature glomeruli were present in the WT mice (Fig. $7 C, E)$. In the $\mathrm{HCN1}^{-/-}$mice glomeruli could be identified at P4 (Fig. 7D), but many appeared morphologically abnormal and not circumscribed (Fig. $7 D, F$ ). It is notable that mature glomeruli, those well delineated by axon fascicles from the overlying olfactory nerve layer, were absent in the $\mathrm{HCN}^{-1-}$ mice (compare Fig. 7, $E$ vs $F$ ). Examination of VGlut2 staining in adult $\mathrm{HCN}^{-/-}$mice showed that the delay in convergence was resolved, although intrinsic organization of the glomerular layer remained irregular and glomeruli are morphologically abnormal (Fig. 8).

We quantified the glomerular layer with counts of VGlut2-labeled foci/glomeruli in matched sections from P4 WT and $\mathrm{HCN}^{-/-}$littermate controls. Despite the aberrant appearance of the glomeruli in the $\mathrm{HCN1}^{-/-}$mice, we did not find a statistically significant difference in the overall number of glomerular-like structures or in their regional distribution. Next, we examined the variation in size and morphology of glomeruli in WT and $\mathrm{HCN}^{-1-}$ mice. We compared the area, perimeter, and circularity of the glomeruli and found that glomeruli from the dorsal $\mathrm{OB}$ of $\mathrm{HCN}^{-/-}$[knock-out $(\mathrm{KO})]$ mice were significantly larger than those in WT animals (area $=195.7 \pm 8.8$ $\mu \mathrm{m}^{2} \mathrm{WT}, 220.7 \pm 8.4 \mu \mathrm{m}^{2} \mathrm{KO}$; $\left.p<0.05\right)$ (Fig. 9A). No significant differences were observed in perimeter or circularity measurements. Next, we divided the OB into $20^{\circ}$ segments and measured how many glomeruli each segment divider crossed in the glomerular layer. The number of glomeruli crossed at each division was significantly greater in $\mathrm{HCN} 1^{-1-}$ mice compared to the WT mice $(0.83 \pm 0.04$ versus $0.72 \pm 0.04$, respectively; $p<0.05$ ) (Fig. $9 B$ ), showing that in the $\mathrm{HCN1}{ }^{-/-}$ mice more glomeruli are radially stacked, contributing to atypical lamination of the glomerular layer.

The aberrant appearance of the glomeruli in the $\mathrm{HCN1}^{-1-}$ mice and the in vitro analysis of OSN neurite extension suggested that organization within the nerve layer may contribute to the overall phenotype in the $\mathrm{HCN}^{-/-}$mice. Although our in vitro analyses demonstrated decreased outgrowth of OSN axons in the $\mathrm{HCN}^{-1-}$ mice and following application of $\mathrm{HCN}$ channel blockers, at E13 in vivo OSN axons have reached the OB and have begun to form an olfactory nerve layer (supplemental Fig. 5, available at www.jneurosci.org as supplemental material). However, the organization of the nerve layer is abnormal in $\mathrm{HCN}^{-1-}$ mice, and the division of the inner and outer nerve layers of the 
OB is perturbed. Peripherin immunoreactivity, a marker of type III intermediate filament protein, is normally limited to the outer nerve layer, whereas NCAM labels both the inner and outer nerve layers (Fig. $10 \mathrm{~A}-\mathrm{C}$ ). However, in $\mathrm{HCN}^{-1-}$ mice peripherinlabeled axons were broadly dispersed across both the outer and inner nerve layers at E17 (Fig. 10D-F). In WT mice there was a consistent decrease in the peripherin:NCAM ratio measured across the outer to inner nerve layer, while in $\mathrm{HCN}^{-1-}$ mice peripherin-labeled axons persisted deeply into the inner nerve layer. These were most pronounced in the dorsolateral rostral $\mathrm{OB}$ $\left(240^{\circ}\right.$; WT $\left.0.61 \pm 0.008 ; \mathrm{HCN}^{-1-} 0.80 \pm 0.04\right)$, the ventral caudal OB $\left(0^{\circ}\right.$; WT $\left.0.35 \pm 0.05 ; \mathrm{HCN}^{-1-} 0.74 \pm 0.07\right)$, and the dorsolateral caudal $\mathrm{OB}\left(240^{\circ}\right)$ at E17 (WT $0.47 \pm 0.14 ; \mathrm{HCN}^{-1-}$ $0.76 \pm 0.08$ ) (supplemental Fig. 6, available at www.jneurosci.org as supplemental material). This phenotype persisted to P4; analyses of the ventral-lateral aspect $\left(300^{\circ}\right)$ of the nerve layer in the caudal $\mathrm{OB}$ showed a significant difference in the peripherin: NCAM ratio in $\mathrm{HCN}^{-1-}$ mice relative to WT mice (WT $0.67 \pm$ 0.05 HCN1 $\left.^{-/-} 1.12 \pm 0.05\right)$. These data support the hypothesis that a disruption of normal axon extension and coalescence in the nerve layer contributes to the perturbation in glomerular formation in the $\mathrm{HCN}^{-1-}$ mice.

OSN axon projections to the $\mathrm{OB}$ are regionally organized; molecular markers, some with known functional roles in axon guidance, have been used to map a broad topography from the $\mathrm{OE}$ to the $\mathrm{OB}$ (de Castro et al., 1999; Lipscomb et al., 2003; Suto et al., 2003; Gussing and Bohm, 2004; Schwarting et al., 2004; Walz et al., 2006; Cho et al., 2007). We used three markers, NQO1, OCAM, and Nrp-1 to test regional organization in the $\mathrm{HCN}^{-l-}$ mice but found no significant differences in staining patterns (supplemental Fig. 7, available at www.jneurosci. org as supplemental material). Thus, while glomerular formation is perturbed, regional topography between the $\mathrm{OE}$ and $\mathrm{OB}$ appears preserved in the $\mathrm{HCN}^{-/-}$ mice.

Finally, we asked whether the glomerulus for a single OR was affected by the deletion of HCN1. To determine whether the position of glomeruli shifted in the $\mathrm{HCN}^{-1-}$ mice we measured the distance of two ORs, MOR28 (P14) and M72 (P21), from the accessory olfactory bulb, a fixed structure located in the most dorsalcaudal OB. The dorsomedial MOR28 glomeruli had a significant change in location in $\mathrm{HCN1}^{-1-}$ mice compared to WT mice (Fig. 11A). The four MOR28 glomeruli in WT mice were all found rostral to the first section containing $\mathrm{AOB}$, while in $\mathrm{HCN1}^{-1-}$ mice the MOR28 glomeruli were all caudal to the first AOB section. There was no significant change in the location of the four M72 glomeruli compared to WT littermates (supplemental Fig. 8, available at www.jneurosci.org as supplemental material), nor did we observe multiple glomeruli at any location or heterozygous glomeruli for either OR (not quanti-

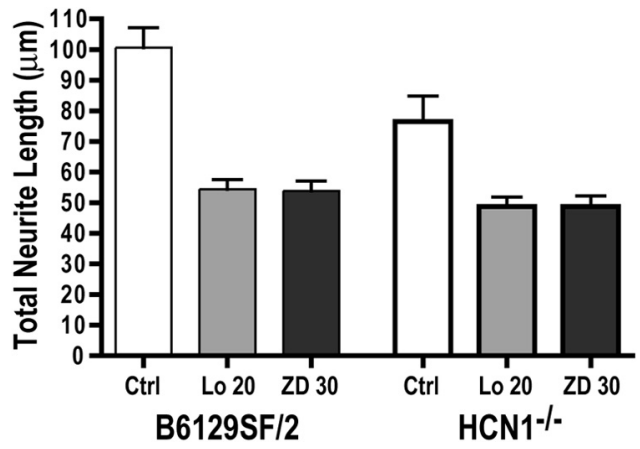

Figure 6. Cultured primary OSNs from control and $\mathrm{HCN} 1^{-1-}$ mice challenged with $20 \mu \mathrm{m}$ loperamide or $30 \mu \mathrm{m} Z \mathrm{ZD} 7288$. Cells from $\mathrm{HCN1}^{-1-}$ mice have significantly reduced neurite length compared to cells from B6129SF/2 mice (Student'st test, $p<0.05$ ) in control conditions In control mice loperamide and ZD 7288 reduce neurite outgrowth 46\% (ANOVA, $p<0.0001$ ) In $\mathrm{HCN} 1^{-1-}$ mice the effect is only $36 \%$ (ANOVA, $p<0.01$ ), suggesting that HCN channels are responsible for the inhibitor effect. Error bars, SEM.
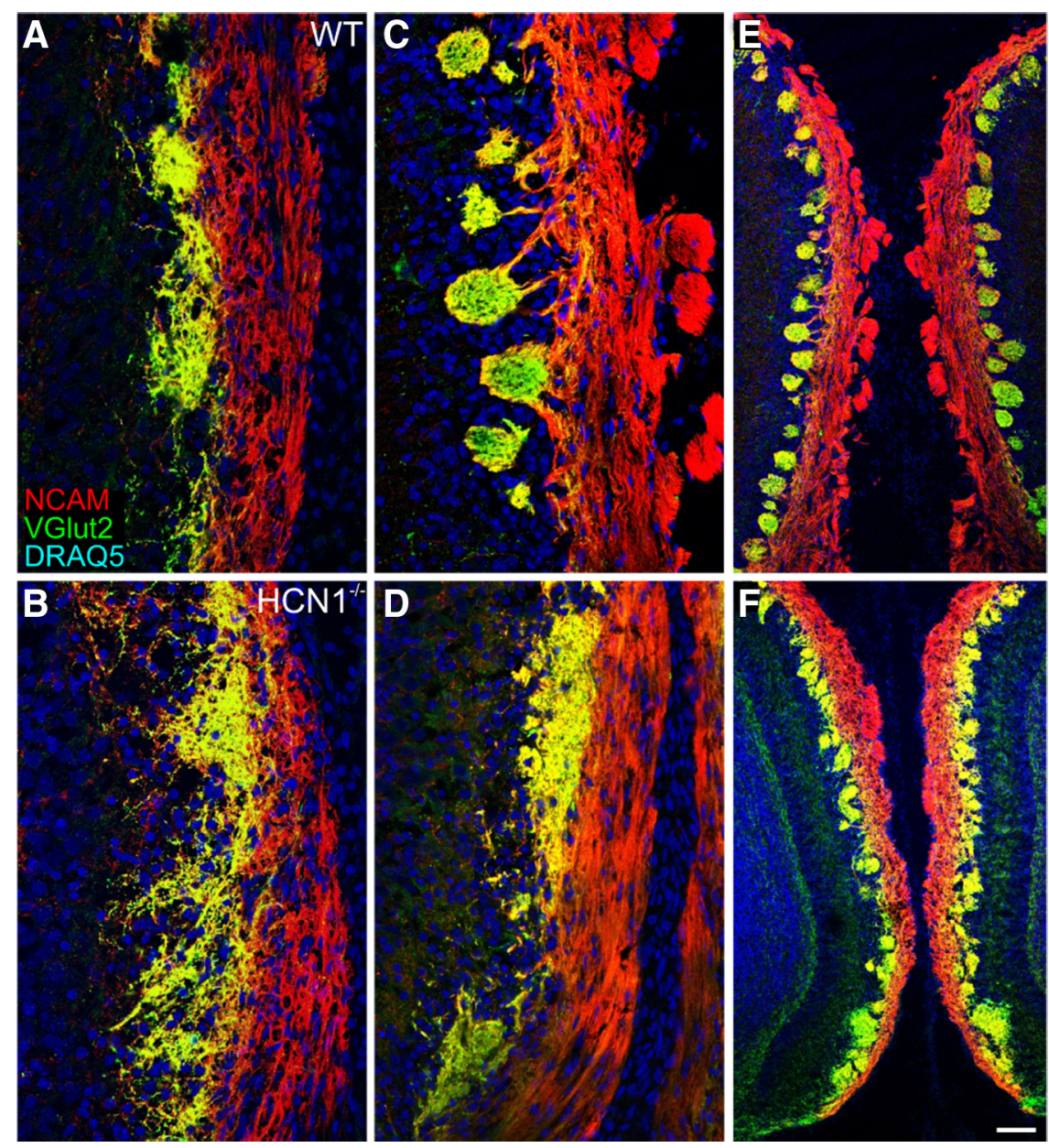

Figure 7. $\mathrm{HCN} 1^{-1-}$ mice have delayed glomerular formation. $\boldsymbol{A}, \boldsymbol{B}$, At E17 protoglomeruli normally seen in WT mice $(\boldsymbol{A})$ have yet to form in $\mathrm{HCN1}^{-1-}$ mice $(\boldsymbol{B})$. $\boldsymbol{C}-\boldsymbol{F}$, At P4 glomeruli can be seen in WT and $\mathrm{HCN} 1^{-1-}$ mice. However, in the $\mathrm{HCN} 1^{-1-}$ mice glomeruli are poorly formed and lack discrete boundaries $(\boldsymbol{D}, \boldsymbol{F})$. Scale bar (in $\boldsymbol{F}$ ), $100 \mu \mathrm{m}$ in $\boldsymbol{A}-\boldsymbol{D} ; 200 \mu \mathrm{m}$ in $\boldsymbol{E}$ and $\boldsymbol{F}$.

fied). Next, we examined coalescence of MOR $28^{+}$axons at P0 in the glomerular layer by measuring pixel intensity from images taken from three consecutive sections. The MOR $28^{+}$axons in WT and $\mathrm{HCN}^{-/-}$mice appeared to coalesce similarly, and pixel intensity values were not significantly different $(p>0.05)$ (Fig. $11 B-E)$. Similarly, coalescence of $\mathrm{M}^{+}{ }^{+}$axons was not signifi- 


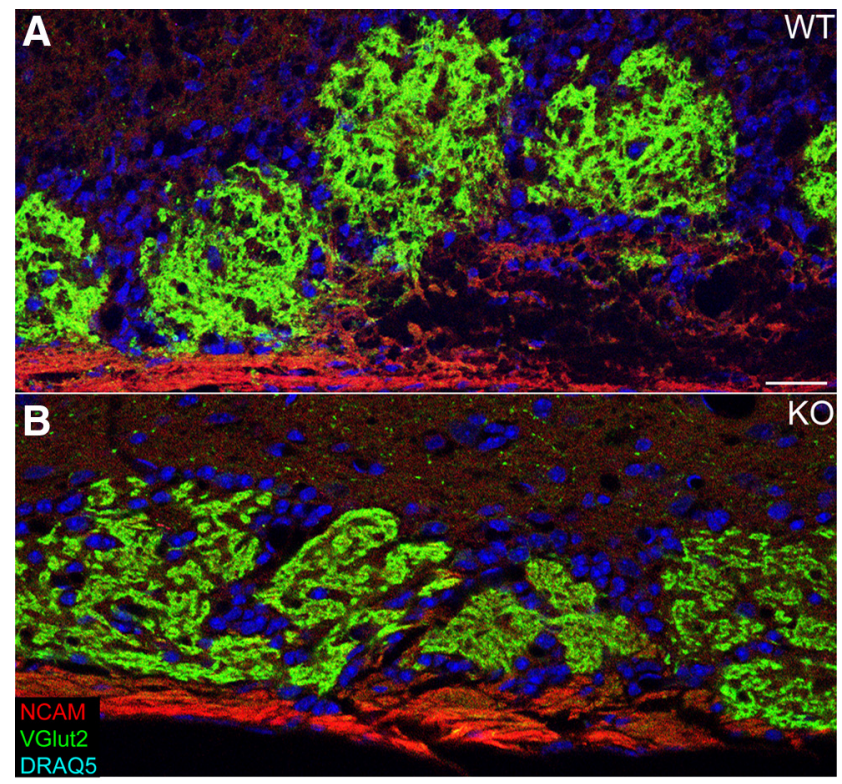

Figure 8. Glomerular layer abnormalities persist in adult $\mathrm{HCN} 1^{-1-}$ mice. $A$, WT mice have discrete, round glomeruli. $\boldsymbol{B}, \mathrm{HCN} 1^{-1-}$ mice have irregularly shaped glomeruli that are not well circumscribed. Scale bar for $\boldsymbol{A}$ and $\boldsymbol{B}$ (in $\boldsymbol{A}), 25 \mu \mathrm{m}$.

cantly different between $\mathrm{WT}$ and $\mathrm{HCN1}^{-1-}$ mice (data not shown). The MOR28 OR is among the first to appear in the developing $\mathrm{OE}$, around $\mathrm{E} 9$, with robust protein expression by E13 (Rodriguez-Gil et al., 2010). Thus, OSNs express MOR28 when $\mathrm{HCN}$ channel expression is predominant among the immature growing axons. In contrast, the M72 OR has a late onset of E16, when $\mathrm{HCN}$ subunits are downregulating expression in immature OSNs (Potter et al., 2001). The temporal expression patterns of these two ORs may account for their differential susceptibility to perturbation in the $\mathrm{HCN} 1^{-/-}$mice.

\section{Discussion}

Here, we characterized HCN channel subunit expression in the developing $\mathrm{OE}$, demonstrated its role in regulating mouse OSN excitability, and presented in vitro and in vivo evidence supporting the hypothesis that $\mathrm{HCN}$ channels play a significant role in OSN axon outgrowth and glomerular layer organization. Expression of all three HCN subunits was detected in the OE at the earliest age examined, E13, and we found developmental relevance in the upregulation of HCN2 and the switch in expression from immature to mature OSNs at E17. Blocking the channels in OSN cell cultures demonstrated a function for HCN channels in neurite outgrowth and branching. Colocalization in OSNs expressing ACIII suggests that HCN channel function may be cAMP sensitive. This is the first data showing that an alternative cation channel contributes to OSN axon extension and suggests that $\mathrm{HCN}$ channels are a probable target of cAMP during development.

The importance of HCN channels in developing OSNs may be inferred by the switch in expression from immature to mature OSNs at E17 and the significant increase in HCN2 expression from E13 through P4. HCN2 is one of the most sensitive subunits to cAMP modulation, with an $\mathrm{EC}_{50}$ of $10 \mathrm{nM}$ in immature hippocampus that shifts activation to a less hyperpolarized potential (Wainger et al., 2001; Surges et al., 2006). Recently, Kusch et al. (2010) reported that ligand binding of cAMP and voltage activation in HCN2 channels are interdependent and that each increases the probability of the other. At E13, HCN subunits were
A

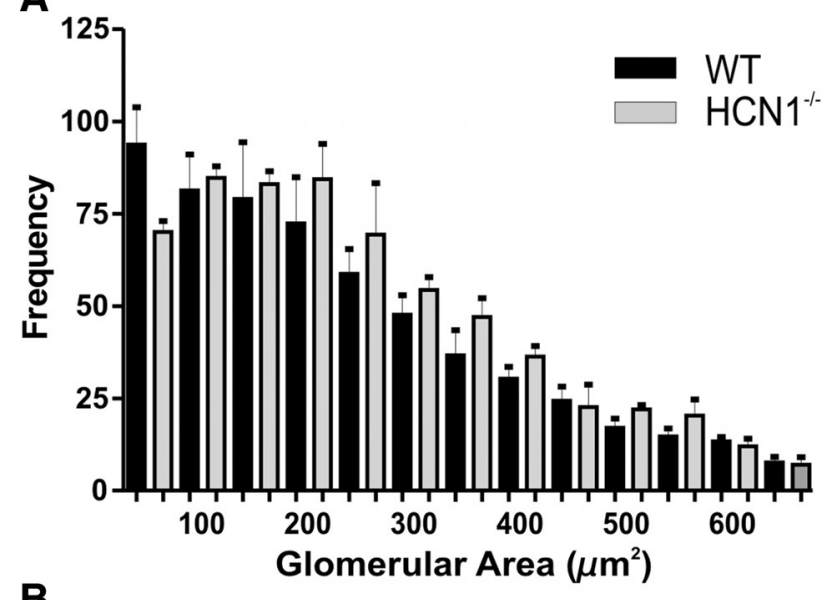

B
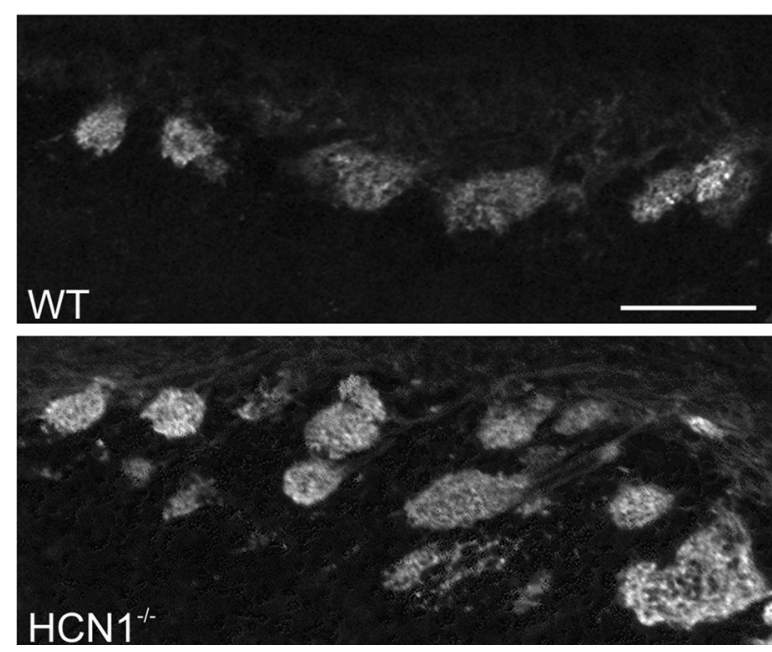

Figure 9. Glomerular size and distribution are perturbed in $\mathrm{P} 4 \mathrm{HCN} 1^{-1-}$ mice. $A$, Binned distribution shows the frequency of glomerular area $\left(\mu \mathrm{m}^{2)}\right.$ among dorsal glomeruli in WT and $\mathrm{HCN} 1^{-l-}$ mice. $\boldsymbol{B}$, VGlut2-labeled sections from similar regions in WT and $\mathrm{HCN}^{-1-}$ mice; note the radial stacking of glomeruli in the $\mathrm{HCN} 1^{-1-}$ mice. Scale bar, $100 \mu \mathrm{m}$. Error bars, SEM.

present in immature OSNs. However, at E17 expression became more robust among the mature OMP-labeled cells, and less so in immature GAP43-labeled cells. Collectively, these data suggest that the role of $I_{\mathrm{h}}$ may be important in initial olfactory system development.

OB protoglomeruli begin to form at E17 (Treloar et al., 2002). In the $\mathrm{HCN1}^{-/-}$mice we found a significant delay in protoglomerular formation and perturbations in nerve layer organization beginning at E17. At P4 there were significant increases in glomerular area and changes to the sublaminar organization of nerve layer axons. The irregular morphology and stacking of glomeruli that we observed at $\mathrm{P} 4$ persisted into adulthood, suggesting that the loss of $\mathrm{HCN} 1$ affected the intrinsic organization of the glomerular layer. While it is possible that an upregulation of other $\mathrm{HCN}$ subunits in the $\mathrm{HCN1}{ }^{-/-}$mice compensate for the loss of HCN1, this seems unlikely or deficient given the striking glomerular and olfactory nerve layer phenotype we describe.

OSN axons expressing only 1 of $\sim 1200$ ORs navigate through the mesenchyme to the $\mathrm{OB}$ and subsequently coalesce with axons expressing the same OR to converge into a glomerulus within a topographically defined location. We had speculated that $\mathrm{HCN}$ subunit expression may exhibit some diversity across subpopulations of OSNs in the OE and contribute to regional axon target- 
ing through diverse channel kinetics. However, at all ages we found that OSNs expressed all three subunits. While regional topography between the $\mathrm{OE}$ and the $\mathrm{OB}$ was not altered in the $\mathrm{HCN} 1^{-1-}$ mice, the MOR28 glomeruli had significant changes in location. Onset of MOR28 mRNA occurs at E9.5, while M72 mRNA expression begins at E16 (Potter et al., 2001; Rodriguez-Gil et al., 2010). HCNs are expressed in immature OSNs only before E17, which may explain their greater effect on MOR28 glomerular location than on M72 glomeruli.

While HCN channels are found in $\mathrm{OB}$ neurons (Moosmang et al., 1999; Holderith et al., 2003; Notomi and Shigemoto, 2004; Brewster et al., 2007), the phenotype we report in the $\mathrm{HCN} 1^{-1-}$ mice is not likely due to deficits in OB neurons. First, we have shown the localization of $\mathrm{HCN}$ subunits to OSNs and demonstrated that they are functionally active. Second, we showed in vitro that $\mathrm{HCN}$ channels regulate OSN axon extension. Third, we found that the organization within the olfactory nerve layer was perturbed in the $\mathrm{HCN1}^{-/-}$mice before the OSN axons interacted with OB neurons. Thus, the most parsimonious explanation for the perturbations in the nerve layer and glomerular layer in the $\mathrm{HCN}^{-/-}$mice is the loss of HCN1 in the OSNs.

$\mathrm{HCN}$ channels contribute to the depolarization of the resting potential and therefore may be considered to increase excitability (Robinson and Siegelbaum, 2003). The presence of cAMP shifts the opening of $\mathrm{HCN} 1$ channels $5.8 \pm 0.6 \mathrm{mV}$ in the depolarizing direction and increases activation by 1.5-fold (Chen et al., 2009). Although the HCN1 subunit is less sensitive to cAMP modulation than HCN2 or HCN4, it activates 4- to 6-fold faster at $\sim 20$ $\mathrm{mV}$ less negative potential (Wainger et al., 2001). Thus, the loss of $\mathrm{HCN} 1$ is expected to decrease excitability by decreased $I_{\mathrm{h}}$ amplitude and activation rate (Chen et al., 2009). The most plausible explanation of the phenotype in $\mathrm{HCN} 1^{-/-}$mice is that decreased excitability affects normal OSN activity, leading to a perturbation of axon behavior. Alternatively, HCN channels may also affect synaptic transmission via direct interaction with the cytoskeleton, and we cannot rule out the possibility that such an effect may contribute to the glomerular phenotype reported here (Beaumont and Zucker, 2000).

Some progress has been made toward determining the requirements necessary for OSN axons to target and converge into a glomerulus within a predefined region of the OB. Among the first was the demonstration that the OR itself is a necessary, though not sufficient, determinant (Feinstein et al., 2004). More recently, Imai et al. (2006) concluded that $\mathrm{G} \alpha_{\mathrm{s}}$-mediated cAMP signals regulate transcription of adhesion-associated molecules, which in turn establish the position of a glomerulus along the rostral-caudal axis. In a complementary study, Chesler et al. (2007) showed that constitutively active G protein was sufficient to induce OSN axon convergence regardless of OR expression. Downstream of the G protein, the loss of ACIII profoundly affects axon projection and the convergence of axons into homogeneous glomeruli (Col et al., 2007; Zou et al., 2007). While ACIII production of cAMP activates the CNG channel during an odor
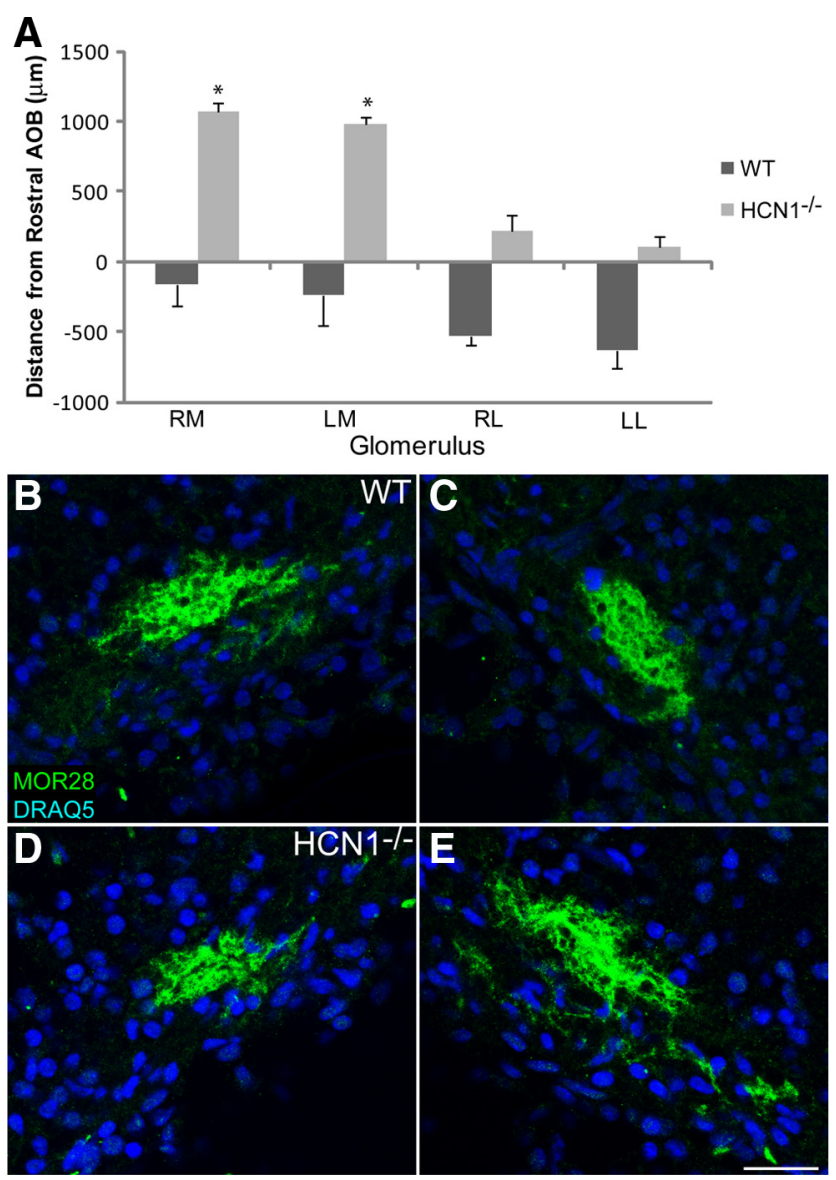

Figure 11. In $\mathrm{HCN}^{-1-}$ mice MOR28 glomeruli change their location but have normal coalescence. $A$, The histogram shows the change in position relative to the first section containing $\mathrm{AOB}$ in the WT compared to $\mathrm{HCN} 1^{-1-}$ mice. $\boldsymbol{B}-\boldsymbol{E}, \mathrm{OB}$ sections from $\mathrm{PO}$ mice labeled with MOR28 and DRAQ5. $B$, C, Left and right medial WT glomeruli, respectively. $\boldsymbol{D}, \boldsymbol{E}$, Left and right medial $\mathrm{HCN}^{-1-}$ glomeruli, respectively. RM, Right medial; LM, left medial; RL, right lateral; $\mathrm{LL}$, left lateral. Scale bar for $\boldsymbol{B}-\boldsymbol{E}$ (in $\boldsymbol{E}), 50 \mu \mathrm{m}$. Error bars, SEM. ${ }^{*} p<0.05$, statistically significant difference from controls. 
response, we propose that during development cAMP targets HCN channels to increase excitability.

The developmental expression of CNG channels has not been determined in mice. However, in rats expression is first seen at E14 (equivalent to mouse E12.5) in basally located cells (Matsuzaki et al., 1999) but does not appear in neurons with a mature morphology until E16 (equivalent to mouse E14.5) and not uniformly across the OE until E18-E19 (equivalent to mouse E16.5E17) (Margalit and Lancet, 1993; Shay et al., 2008). Interestingly, although the CNG channels have a developmental profile similar to that of the HCN channels, targeted mutations in the $\mathrm{CNG}$ $\alpha$-subunit (CNG $\mathrm{KO}$ ) result in only minor changes in axonal convergence into a glomerulus (Lin et al., 2000), in contrast to the more pronounced phenotype we report here in the $\mathrm{HCN}^{-1-}$. Moreover, expression of genes related to axon extension were shown to be activity dependent in OSNs (Yu et al., 2004; Biju et al., 2008). Our data suggest that some of this activity may be accounted for by the HCN channels. From E17 to P4, glomerular layer development is delayed in $\mathrm{HCN}^{-1-}$ mice with persistent disorganization in adults, arguing that $\mathrm{HCN} 1$ is necessary for the initial formation of protoglomeruli and glomerular maturation. This finding is consistent with prior reports (Imai et al., 2006; Chesler et al., 2007) showing that increases in OSN axon extension/coalescence occur following elevation of cAMP, but are independent of CNG channels. Finally, with overexpression of Kir2.1, "giant glomerulus-like structures" are found in the dorsal OB (Yu et al., 2004). Although the Kir2.1 current is large (1 nA) (Rodríguez-Menchaca et al., 2008) compared to $I_{\mathrm{h}}$, the changes in glomerular size are reminiscent of those found here following mutation of HCN1. Similarly, the dorsal OB glomeruli and glomerular layer in ACIII ${ }^{-/-}$mice is strikingly similar to our findings in $\mathrm{HCN}^{-1-}$ mice (Zou et al., 2007). Thus, both overexpression of Kir2.1 or the loss of ACIII, both of which decrease excitability in OSNs, produce phenotypes comparable to those seen in the $\mathrm{HCN}_{1}{ }^{-1-}$ mice, supporting our conclusion that they may reflect a common mechanism.

While the subcellular site of action for $I_{\mathrm{h}}$ regulation of OSN axon behavior is not yet known, it is generally recognized that both calcium and cAMP regulate the behavior of growth cones (Ming et al., 1997; Zheng, 2000). Two recent reports showed that OR mRNA is transported to OSN axons/growth cones and that odors can induce cAMP-dependent calcium increases (Maritan et al., 2009; Dubacq et al., 2009). HCN channels are present in OSN axons, the presynaptic compartments of developing hippocampal neurons (Bender et al., 2007), and our in vitro data show protein expression in the neurites of developing OSNs. Future studies are being undertaken to determine the effect of cAMP on $I_{\mathrm{h}}$ in mouse OSNs, downstream effects of $I_{\mathrm{h}}$, and HCN channel expression in the growth cone.

In summary, we established the developmental profile of HCN channels in mouse OSNs and demonstrated that $I_{\mathrm{h}}$ is a determinant of OSN axon extension and glomerular formation. Our data contribute to a growing body of work suggesting that embryonic activity is essential for the proper development of the olfactory system.

\section{References}

Beaumont V, Zucker RS (2000) Enhancement of synaptic transmission by cyclic AMP modulation of presynaptic Ih channels. Nat Neurosci 3:133-141.

Bender RA, Kirschstein T, Kretz O, Brewster AL, Richichi C, Rüschenschmidt C, Shigemoto R, Beck H, Frotscher M, Baram TZ (2007) Localization of HCN1 channels to presynaptic compartments: novel plasticity that may contribute to hippocampal maturation. J Neurosci 27:4697-4706.
Biju KC, Marks DR, Mast TG, Fadool DA (2008) Deletion of voltage-gated channel affects glomerular refinement and odorant receptor expression in the mouse olfactory system. J Comp Neurol 506:161-179.

Bozza TC, Kauer JS (1998) Odorant response properties of convergent olfactory receptor neurons. J Neurosci 18:4560-4569.

Brewster AL, Chen Y, Bender RA, Yeh A, Shigemoto R, Baram TZ (2007) Quantitative analysis and subcellular distribution of mRNA and protein expression of the hyperpolarization-activated cyclic nucleotide-gated channels throughout development in rat hippocampus. Cereb Cortex 17:702-712.

Brunet LJ, Gold GH, Ngai J (1996) General anosmia caused by a targeted disruption of the mouse olfactory cyclic nucleotide-gated cation channel. Neuron 17:681-693.

Chen S, Wang J, Siegelbaum SA (2001) Properties of hyperpolarizationactivated pacemaker current defined by coassembly of HCN1 and HCN2 subunits and basal modulation by cyclic nucleotide. J Gen Physiol 117:491-504.

Chen X, Shu S, Kennedy DP, Willcox SC, Bayliss DA (2009) Subunitspecific effects of isoflurane on neuronal Ih in HCN1 knock-out mice. J Neurophysiol 101:129-140.

Chesler AT, Zou DJ, Le Pichon CE, Peterlin ZA, Matthews GA, Pei X, Miller MC, Firestein S (2007) A G protein/cAMP signal cascade is required for axonal convergence into olfactory glomeruli. Proc Natl Acad Sci U S A 104:1039-1044.

Cho JH, Lépine M, Andrews W, Parnavelas J, Cloutier JF (2007) Requirement for Slit-1 and Robo-2 in zonal segregation of olfactory sensory neuron axons in the main olfactory bulb. J Neurosci 27:9094-9104.

Col JA, Matsuo T, Storm DR, Rodriguez I (2007) Adenylyl cyclasedependent axonal targeting in the olfactory system. Development 134:2481-2489.

de Castro F, Hu L, Drabkin H, Sotelo C, Chédotal A (1999) Chemoattraction and chemorepulsion of olfactory bulb axons by different secreted semaphorins. J Neurosci 19:4428-4436.

Dibattista M, Mazzatenta A, Grassi F, Tirindelli R, Menini A (2008) Hyperpolarization-activated cyclic nucleotide-gated channels in mouse vomeronasal sensory neurons. J Neurophysiol 100:576-586.

Dubacq C, Jamet S, Trembleau A (2009) Evidence for developmentally regulated local translation of odorant receptor mRNAs in the axons of olfactory sensory neurons. J Neurosci 29:10184-10190.

Feinstein P, Mombaerts P (2004) A contextual model for axonal sorting into glomeruli in the mouse olfactory system. Cell 117:817-831.

Feinstein P, Bozza T, Rodriguez I, Vassalli A, Mombaerts P (2004) Axon guidance of mouse olfactory sensory neurons by odorant receptors and the beta2 adrenergic receptor. Cell 117:833-846.

Frings S, Lynch JW, Lindemann B (1992) Properties of cyclic nucleotidegated channels mediating olfactory transduction: activation, selectivity, and blockage. J Gen Physiol 100:45-67.

Gasparini S, DiFrancesco D (1997) Action of the hyperpolarizationactivated current (Ih) blocker ZD 7288 in hippocampal CA1 neurons. Pflugers Arch 435:99-106.

Gussing F, Bohm S (2004) NQO1 activity in the main and the accessory olfactory systems correlates with the zonal topography of projection maps. Eur J Neurosci 19:2511-2518.

Hanson MG, Landmesser LT (2004) Normal patterns of spontaneous activity are required for correct motor axon guidance and the expression of specific guidance molecules. Neuron 43:687-701.

Holderith NB, Shigemoto R, Nusser Z (2003) Cell type-dependent expression of HCN1 in the main olfactory bulb. Eur J Neurosci 18:344-354.

Imai T, Suzuki M, Sakano H (2006) Odorant receptor-derived cAMP signals direct axonal targeting. Science 314:657-661.

Kusch J, Biskup C, Thon S, Schulz E, Nache V, Zimmer T, Schwede F, Benndorf K (2010) Interdependence of receptor activation and ligand binding in HCN2 pacemaker channels. Neuron 67:75-85.

Lagostena L, Menini A (2003) Whole-cell recordings and photolysis of caged compounds in olfactory sensory neurons isolated from the mouse. Chem Senses 28:705-716.

Lee YT, Vasilyev DV, Shan QJ, Dunlop J, Mayer S, Bowlby MR (2008) Novel pharmacological activity of loperamide and CP-339,818 on human HCN channels characterized with an automated electrophysiology assay. Eur J Pharmacol 581:97-104.

Lin DM, Wang F, Lowe G, Gold GH, Axel R, Ngai J, Brunet L (2000) For- 
mation of precise connections in the olfactory bulb occurs in the absence of odorant-evoked neuronal activity. Neuron 26:69-80.

Lipscomb BW, Treloar HB, Klenoff J, Greer CA (2003) Cell surface carbohydrates and glomerular targeting of olfactory sensory neuron axons in the mouse. J Comp Neurol 467:22-31.

Lynch JW, Barry PH (1991) Inward rectification in rat olfactory receptor neurons. Proc Biol Sci 243:149-153.

Margalit T, Lancet D (1993) Expression of olfactory receptor and transduction genes during rat development. Brain Res Dev Brain Res 73:7-16.

Maritan M, Monaco G, Zamparo I, Zaccolo M, Pozzan T, Lodovichi C (2009) Odorant receptors at the growth cone are coupled to localized cAMP and $\mathrm{Ca}^{2+}$ increases. Proc Natl Acad Sci U S A 106:3537-3542.

Matsuzaki O, Bakin RE, Cai X, Menco BP, Ronnett GV (1999) Localization of the olfactory cyclic nucleotide-gated channel subunit 1 in normal, embryonic and regenerating olfactory epithelium. Neuroscience 94:131-140.

Ming GL, Song HJ, Berninger B, Holt CE, Tessier-Lavigne M, Poo MM (1997) cAMP-dependent growth cone guidance by netrin-1. Neuron 19:1225-1235.

Mombaerts P, Wang F, Dulac C, Chao SK, Nemes A, Mendelsohn M, Edmondson J, Axel R (1996) Visualizing an olfactory sensory map. Cell 87:675-686.

Moosmang S, Biel M, Hofmann F, Ludwig A (1999) Differential distribution of four hyperpolarization-activated cation channels in mouse brain. Biol Chem 380:975-980.

Müller F, Scholten A, Ivanova E, Haverkamp S, Kremmer E, Kaupp UB (2003) HCN channels are expressed differentially in retinal bipolar cells and concentrated at synaptic terminals. Eur J Neurosci 17:2084-2096.

Notomi T, Shigemoto R (2004) Immunohistochemical localization of Ih channel subunits, HCN1-4, in the rat brain. J Comp Neurol 471:241-276.

Potter SM, Zheng C, Koos DS, Feinstein P, Fraser SE, Mombaerts P (2001) Structure and emergence of specific olfactory glomeruli in the mouse. J Neurosci 21:9713-9723.

Robinson RB, Siegelbaum SA (2003) Hyperpolarization-activated cation currents: from molecules to physiological function. Annu Rev Physiol 65:453-480.

Rodriguez-Gil DJ, Treloar HB, Zhang X, Miller AM, Two A, Iwema C, Firestein SJ, Greer CA (2010) Chromosomal location-dependent nonstochastic onset of odor receptor expression. J Neurosci 30:10067-10075.

Rodríguez-Menchaca AA, Navarro-Polanco RA, Ferrer-Villada T, Rupp J, Sachse FB, Tristani-Firouzi M, Sánchez-Chapula JA (2008) The molecular basis of chloroquine block of the inward rectifier Kir2.1 channel. Proc Natl Acad Sci U S A 105:1364-1368.

Sakano H (2010) Neural map formation in the mouse olfactory system. Neuron 67:530-542.

Schwarting GA, Raitcheva D, Crandall JE, Burkhardt C, Püschel AW (2004) Semaphorin 3A-mediated axon guidance regulates convergence and targeting of P2 odorant receptor axons. Eur J Neurosci 19:1800-1810.

Serizawa S, Miyamichi K, Takeuchi H, Yamagishi Y, Suzuki M, Sakano H (2006) A neuronal identity code for the odorant receptor-specific and activity-dependent axon sorting. Cell 127:1057-1069.

Shay EL, Greer CA, Treloar HB (2008) Dynamic expression patterns of ECM molecules in the developing mouse olfactory pathway. Dev Dyn 237:1837-1850.

Singh KK, Miller FD (2005) Activity regulates positive and negative neurotrophin-derived signals to determine axon competition. Neuron 45:837-845.

Surges R, Brewster AL, Bender RA, Beck H, Feuerstein TJ, Baram TZ (2006) Regulated expression of HCN channels and cAMP levels shape the properties of the $h$ current in developing rat hippocampus. Eur J Neurosci 24:94-104.

Suto F, Murakami Y, Nakamura F, Goshima Y, Fujisawa H (2003) Identification and characterization of a novel mouse plexin, plexin-A4. Mech Dev 120:385-396.

Treloar HB, Feinstein P, Mombaerts P, Greer CA (2002) Specificity of glomerular targeting by olfactory sensory axons. J Neurosci 22:2469-2477.

Treloar HB, Miller AM, Ray A, Greer CA (2009) Development of the olfactory system. In: The neurobiology of olfaction (Menini A, ed), pp 131156. Boca Raton, FL: CRC.

Vargas G, Lucero MT (1999) Dopamine modulates inwardly rectifying hyperpolarization-activated current (Ih) in cultured rat olfactory receptor neurons. J Neurophysiol 81:149-158.

Vasilyev DV, Shan Q, Lee Y, Mayer SC, Bowlby MR, Strassle BW, Kaftan EJ, Rogers KE, Dunlop J (2007) Direct inhibition of Ih by analgesic loperamide in rat DRG neurons. J Neurophysiol 97:3713-3721.

Wainger BJ, DeGennaro M, Santoro B, Siegelbaum SA, Tibbs GR (2001) Molecular mechanism of cAMP modulation of $\mathrm{HCN}$ pacemaker channels. Nature 411:805-810.

Walz A, Mombaerts P, Greer CA, Treloar HB (2006) Disrupted compartmental organization of axons and dendrites within olfactory glomeruli of mice deficient in the olfactory cell adhesion molecule, OCAM. Mol Cell Neurosci 32:1-14.

Wang F, Nemes A, Mendelsohn M, Axel R (1998) Odorant receptors govern the formation of a precise topographic map. Cell 93:47-60.

Williams DK, Cohan CS (1995) Calcium transients in growth cones and axons of cultured Helisoma neurons in response to conditioning factors. J Neurobiol 27:60-75.

Ye B, Nerbonne JM (2009) Proteolytic processing of HCN2 and coassembly with HCN4 in the generation of cardiac pacemaker channels. J Biol Chem 284:25553-25559.

Yu CR, Power J, Barnea G, O’Donnell S, Brown HE, Osborne J, Axel R, Gogos JA (2004) Spontaneous neural activity is required for the establishment and maintenance of the olfactory sensory map. Neuron 42:553-566.

Zagotta WN, Siegelbaum SA (1996) Structure and function of cyclic nucleotide-gated channels. Annu Rev Neurosci 19:235-263.

Zhao H, Reed RR (2001) X inactivation of the OCNC1 channel gene reveals a role for activity-dependent competition in the olfactory system. Cell 104:651-660.

Zheng C, Feinstein P, Bozza T, Rodriguez I, Mombaerts P (2000) Peripheral olfactory projections are differentially affected in mice deficient in a cyclic nucleotide-gated channel subunit. Neuron 26:81-91.

Zheng JQ (2000) Turning of nerve growth cones induced by localized increases in intracellular calcium ions. Nature 403:89-93.

Zhou L, Olivier NB, Yao H, Young EC, Siegelbaum SA (2004) A conserved tripeptide in $\mathrm{CNG}$ and $\mathrm{HCN}$ channels regulates ligand gating by controlling C-terminal oligomerization. Neuron 44:823-834.

Zou DJ, Chesler AT, Le Pichon CE, Kuznetsov A, Pei X, Hwang EL, Firestein S (2007) Absence of adenylyl cyclase 3 perturbs peripheral olfactory projections in mice. J Neurosci 27:6675-6683.

Zou DJ, Chesler A, Firestein S (2009) How the olfactory bulb got its glomeruli: a just so story. Nat Rev Neurosci 10:611-618. 